\title{
Characteristics Of Aluminium ADC 12/SiC Composite with the Addition of TiB and Sr Modifier
}

\author{
Astari Indarsari ${ }^{1}$, Anne Zulfia Syahrial ${ }^{1 *}$, and Budi Wahyu Utomo $^{2}$ \\ ${ }^{1}$ Department of M etallurgy and M aterials Engineering, U niversity of Indonesia, JI. M argonda Raya, \\ Pondok Cina, Depok, W est J ava, 16424, Indonesia \\ ${ }^{2} \mathrm{~A}$ stra H onda M otor, J I. Raya K al imantan, Cikarang, B ekasi, W est J ava, 17530, Indonesia
}

\begin{abstract}
The addition of silicon carbide $(\mathrm{SiC})$ as a reinforce in a composite can improve mechanical properties. In this study aluminium ADC 12 (Al-Si-Aluminium Alloy) is treated with an addition of $\mathrm{SiC}$ varied from $(1 ; 1.5 ; 2 ; 2.5$ to 3$) \mathrm{vf} \%$ and mixed with $0.18 \mathrm{wt} \% \mathrm{Sr}$ to change the morphology of the silicone eutectic phase and $0.15 \mathrm{wt} \%$ titanium boron (TiB) was added as a grain refiner as well as the addition of $5 \mathrm{wt} \%$ magnesium $(\mathrm{Mg})$ to increase the wettability. All materials were fabricated by stir cast method. This research is conducted to obtain the candidate material for application in train's brake shoe and bearing. This kind of usage requires high mechanical properties such as wear resistance, thermal resistance, good elastic modulus and lightweight. The composites were characterised by both mechanical properties and microstructure. The result shows that there is an increase in the mechanical properties of aluminium ADC $12 / \mathrm{SiC}$ composite compared to unreinforced with the value of $144 \mathrm{MPa}$ of strength, $53 \mathrm{HRB}$ of hardness, and $0.0049 \mathrm{~mm}^{3} \mathrm{~m}^{-1}$ of wear rate. As a result, the higher addition of the $\mathrm{SiC}$ results in the better mechanical properties for the composite.
\end{abstract}

Keywords: ADC12, composite aluminium, grain refiner TiB, micro-SiC, modifying agent $\mathrm{Sr}$

\section{Introduction}

The composites are different from the metal alloys, wherein the compound of the materials used has different chemical, physical, and mechanical properties. The main components of the composite are the matrix and reinforce [1]. Composite has been used to manufacture industry, especially for the automotive industry. ADC 12 is used as a composite matrix which is an aluminum alloy with a composition of Silicon $<12 \%$, ADC 12 have a relatively lightweight, corrosion resistance, high thermal conductivity, and ductile [2]. The fabrication of this Aluminum composite consists of $\mathrm{SiC}$ particles as a reinforcement, $\mathrm{TiB}$ as

\footnotetext{
${ }^{*}$ Corresponding author:b anne@ metal.ui.ac.id
} 
a grain refiner, and Sr modifier, manufactured by stir casting method. This research is conducted obtain homogeneous particle distribution, and the escalation of various mechanical properties, so that it exceeds the aluminium ADC 12 tensile strength, 98.36 $\mathrm{MPa}$ and hardness value $35.03 \mathrm{HRB}$ [3].

Silicon carbide used as a reinforce in the ADC 12 matrix because silicon carbide has a high strength, high stiffness modulus, and resistance to high temperature [4]. Size particle of $\mathrm{SiC}$ can improve the mechanical properties of bending strength on aluminium composites. In this study using microparticles of $\left(10^{-6}\right)$ so that $\mathrm{SiC}$ is more easily dispersed and improves the mechanical properties [5]. The addition of strontium must be at the optimum composition because if the levels of strontium added to exceed the optimal level, it will tend to occur porosity and the formation of intermetallic compounds in the composite matrix and will reduce the resulting mechanical properties [6]. The addition of $\mathrm{Sr}$ can change the $\mathrm{Al}$ dendritic into equiaxed and reduced secondary dendrite arm spacing (SDAS) in primary Al, and the Al-Si eutectic phase becomes more fibrous [7]. The influence of the addition of $\mathrm{TiB}$ is that can reduce the porosity because it minimises the occurrence of hot tearing resulting in uniform structure [8]. Based on the research with the addition of $0.015 \% \mathrm{Sr}$ to $\mathrm{Al}-11.6 \% \mathrm{Si}$ resulted in the morphology of $\alpha$-Al phase changed to be more columnar, and with the increased $\mathrm{Sr}$ dendrite arm spacing is decreased [9]. The wettability between the matrix and reinforce affect the quality of the composite. An addition Magnesium into the composite as a wetting agent to increase the wettability at a temperature range of $750{ }^{\circ} \mathrm{C}$ to $1100{ }^{\circ} \mathrm{C}$ and reduced contact angle by eliminating the oxide-forming reaction occurring at high temperatures, so that the wettability of the reinforcing particles can be increased [10]. The above explanation shows that the study of aluminium composite $\mathrm{ADC} 12$ with $\mathrm{SiC}$ particle with $\mathrm{TiB}$ as a grain refiner and $\mathrm{Sr}$ as a modifier manufactured by stir casting method can increase the mechanical properties, such as high wear resistance, hardness and toughness, resistant to high temperature and low density.

\section{Experiments}

\subsection{Material analysis of ADC 12/SiC compound}

Aluminium ADC 12 ingot $568 \mathrm{~g}$ was melted in the tilting furnace at temperature $800{ }^{\circ} \mathrm{C}$. In addition of the variation of $\mathrm{SiC}$ particle $(1 ; 1.5 ; 2 ; 2.5 ; 3) \mathrm{vf} \%$ were heated at $900{ }^{\circ} \mathrm{C}$ for $1 \mathrm{~h}$. After ADC 12 was melted, a degassing process is performed in a circular motion using Argon (Ar) gas for 2 min to reduce hydrogen solubility $\left(\mathrm{H}_{2}\right)$ and proceed with the removal of slag formed on the surface of the molten metal. $5 \mathrm{wt} \%$ of $\mathrm{Mg}, 0.03 \mathrm{wt} \%$ of $\mathrm{Al}-\mathrm{Sr}$ and $0.15 \mathrm{wt} \%$ of Al-5Ti-B were added into the crucible followed by stirring for $5 \mathrm{~min}$. Afterwards, the reinforce was poured into melted alloy then stirred with a speed of $519 \mathrm{rpm}$ and degassing process with argon. The metal mold was inserted into the furnace for 2 min at a temperature of $300{ }^{\circ} \mathrm{C}$ to avoid any thermal shock. While the casting die was heated, the molten aluminium stirred for $2 \mathrm{~min}$. Then tilt the molten composite into a metal casting die and cooled at room temperature.

\subsection{Characterization}

For the microstructural observation all specimen characterised by Optical Microscope $(\mathrm{OM})$, for the preparation, the sample were grinded, then plosihed by $\mathrm{TiO}_{2}$, and followed by etchic using $0.5 \%$ Hydrofluoric Acid for $10 \mathrm{~s}$. The chemical composition was observed using Optical emmission Specstroscopy (OES) test, the highest Ultimate tensile strength 
(UTS) specimen was tested by X-Ray Diffraction (XRD) to know the phase present in the composite material.

All samples were consist of tensile tested based on ASTM E8, then hardness test with Rockwell B according to ASTM E18, also followed by wear testing with Ogoshi based on A STM G99, and the density invesigation using A rchimedes method.

\section{Results and discussion}

\subsection{Material and microstructures}

In Figure 1(a) is a microstructure of the matrix used in the composite of Base Aluminum $\mathrm{ADC}$ 12. The phase contained in the ADC 12 matrix material is composed of $\alpha$-Al which is the main phase in the alloy, grey acicular eutectic, $\mathrm{Al}_{2} \mathrm{Cu}$ phase, and $\beta$ phase $\left(\mathrm{Al}_{5} \mathrm{FeSi}\right)$ in the form of needle like. In Figure 1(b), 1(c), 1(d), 1(e) and 1(f) are composites with matrix $\mathrm{ADC} 12$ were added by $\mathrm{Sr}, \mathrm{TiB}, \mathrm{Mg}$ and variaty of $\mathrm{SiC}$ particles. When seen in Figure 3, the phases formed in the $\mathrm{ADC} 12 / \mathrm{SiC}$ composite with the addition of $\mathrm{Sr}$ and $\mathrm{TiB}$ are $\alpha$-Al phase, the blocky $\mathrm{Mg}_{2} \mathrm{Si}$ primary phase, $\mathrm{Mg}_{2} \mathrm{Si}$ binary eutectic in the form of chinese script, $\beta$ phase $(\mathrm{AlFeSi})$ in needle like shape, $\mathrm{Al}_{2} \mathrm{Cu}$ phase which is gray and acicular.

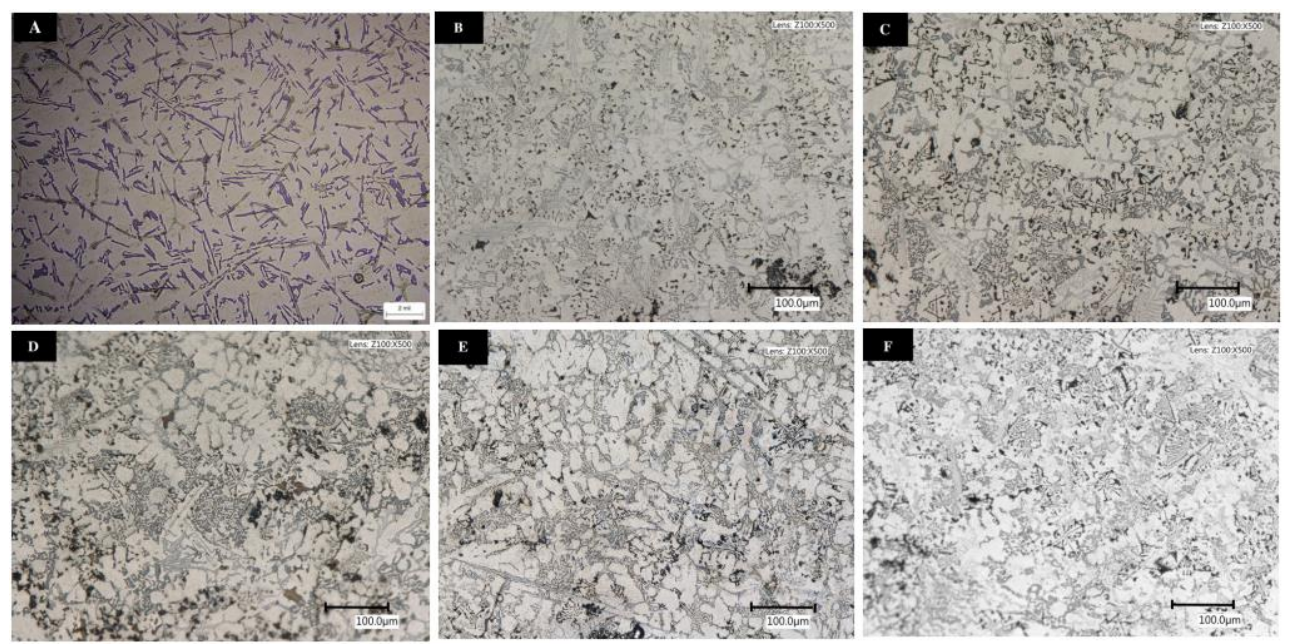

Fig. 1. Observation by using Optical Microscope, Microstructure (a)Base Material ADC12 with 200X magnification, Material with SiC Variation with magnification $500 \times$ (b) 1 vf.\% (C) 1.5 vf.\% (D) 2 vf.\% (E) 2.5 vf.\% (f) 3 vf.\% and the addition of $\mathrm{Sr}$ and $\mathrm{TiB}$

In Figure 2 shows the value of Secondary Dendrite Arm Spacing (SDAS) which decreases on the variation of $\mathrm{SiC}$ addition from $(1 ; 1.5 ; 2 ; 2.5 ; 3) \mathrm{vf} \%$ with SDAS length was $24.38 \mu \mathrm{m} ; 21.85 \mu \mathrm{m} ; 20.78 \mu \mathrm{m} ; 18.11 \mu \mathrm{m} ; 18.02 \mu \mathrm{m}$ respectively. This is also proven that the addition of $\mathrm{wt} \% \mathrm{SiC}$ of 5 to $15 \mathrm{wt} \%$ the value of SDAS is reduced but not very significant [11]. In addition of $0.15 \mathrm{wt} \% \mathrm{TiB}$ and $0.03 \mathrm{wt} \% \mathrm{Sr}$ on the composite ADC $12 / \mathrm{SiC}$ also affects the decreases of SDAS, with an addition of the $\mathrm{wt} \% \mathrm{TiB}$ will bw decrease grain size significantly on the $\mathrm{A} 356 / \mathrm{SiC}$ [12]. And also the addition of strontium affects the growth of dendritic columnar in Al-Si alloys. As the growth of strontium, grain morphology becomes more columnar [11]. 


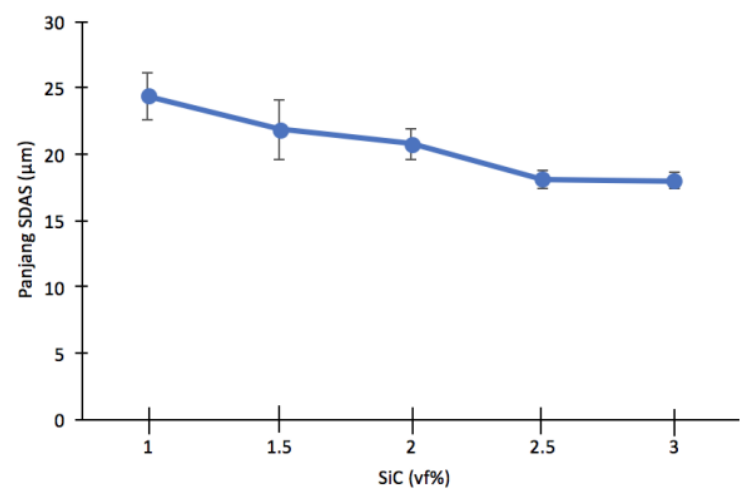

Fig. 2. The effect of addition SiC to Secondary Dendrite Arm Spacing (SDAS).

Table 1. The chemical composition of composites.

\begin{tabular}{|c|c|c|c|c|c|c|}
\hline \multirow{2}{*}{ Element } & \multicolumn{7}{|c|}{ The Composition (wt\%) } \\
\cline { 2 - 7 } & \multirow{2}{*}{ ADC 12 } & $\begin{array}{c}\text { SiC } \\
\mathbf{1 \% v f}\end{array}$ & $\begin{array}{c}\text { SiC } \\
\mathbf{1 . 5 \%}\end{array}$ & $\begin{array}{c}\text { SiC } \\
\mathbf{2 \% v f}\end{array}$ & $\begin{array}{c}\text { SiC } \\
\mathbf{2 . 5 \%} \text { \%f }\end{array}$ & $\begin{array}{c}\text { SiC } \\
\mathbf{3 \%}\end{array}$ \\
\hline $\mathrm{Al}$ & 84.8 & 63.4 & 66.7 & 69.1 & 67 & 71.9 \\
\hline $\mathrm{Si}$ & 10.5 & 11.03 & 11.14 & 11.13 & 11.59 & 12.61 \\
\hline $\mathrm{Fe}$ & 0.864 & 1.13 & 1.05 & 1.02 & 1.92 & 1.55 \\
\hline $\mathrm{Cu}$ & 2.33 & 3.22 & 3.82 & 3.00 & 2.94 & 2.92 \\
\hline $\mathrm{Mg}$ & 0.221 & 5.35 & 6.04 & 5.96 & 4.31 & 5.19 \\
\hline $\mathrm{Cr}$ & 0.0389 & 0.0395 & 0.16 & 0.043 & 0.112 & 0.042 \\
\hline $\mathrm{Ni}$ & 0.0759 & 0.0519 & 0.142 & 0.055 & 0.046 & 0.060 \\
\hline $\mathrm{Ti}$ & 0.0462 & 0.065 & 0.075 & 0.082 & 0.08 & 0.084 \\
\hline $\mathrm{Sr}$ & $<0.0001$ & 0.0037 & 0.0039 & 0.0040 & 0.0039 & 0.0039 \\
\hline
\end{tabular}

As seen in Table 1. from OES test there is an increase in the amount of Si content in the addition of $\mathrm{SiC}(1 ; 1.5 ; 2 ; 2.5 ; 3) \mathrm{vf} \%$ these match with the mass balance. The suitability between the mass balance and the composite ADC 12, where the Si in base ADC 12 is $10.5 \mathrm{wt} \%$ and increased in the composite ADC 12 into $12.61 \mathrm{wt} \%$ due to the addition of $\mathrm{SiC}$ to the composite ADC 12.

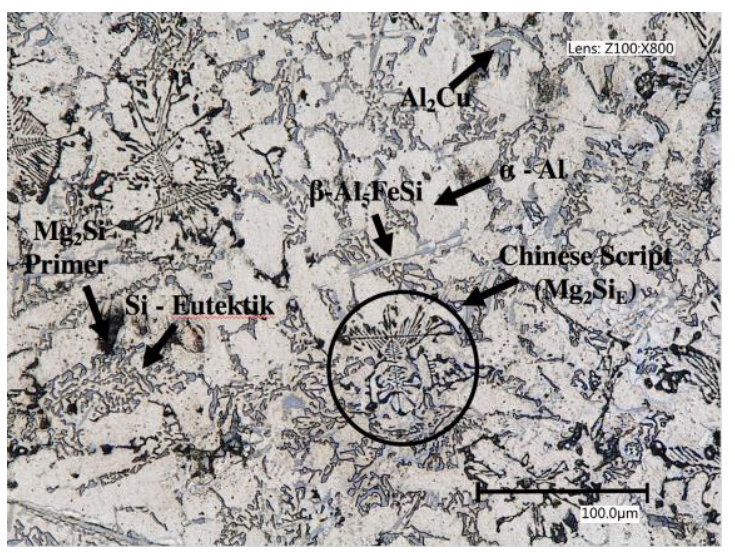

Fig 3. Intermetallic phase with Optical Microscope (OM) with Magnification $800 \times$. 
Micrographs of composites ADC 12 are shown in Figure 3 shows indicate intermetallic phases. From Figure 3 the arrows show the different phases present in the microstructure. $\alpha$-Al phase has the lightest colour, the slightly grey colour known as $\mathrm{Al}_{2} \mathrm{Cu}$, also $\mathrm{Mg}_{2} \mathrm{Si}$ eutectic phase known as chinese script whreas the blocky phase that was $\mathrm{Mg}_{2} \mathrm{Si}$ Primary, and $\beta_{\mathrm{Al}_{5} \mathrm{FeSi}}$ has a needle like forms were also present in the microstructure. The phases were predicted by creating solidification path on ternary phase diagram [13]. The $\beta$ $\mathrm{A} 15 \mathrm{FeSi}$ phase is easily formed in the normal melting and casting conditions, and the $\beta$ Al5FeSi phase can also trigger shrinkage voids in order to decrease the mechanical properties of a material [14]. The reaction forms $\beta$-Al5FeSi:

$$
\mathrm{L}+\beta(\mathrm{AlFeSi}) \rightarrow \mathrm{FeSiAl}_{5} .
$$

This reaction occurs at temperature $595{ }^{\circ} \mathrm{C}$ [13]. $\mathrm{Mg}_{2} \mathrm{Si}$ is a stable intermetallic phase in $\mathrm{Mg}-\mathrm{Si}$ binary. The phase has a high melting temperature, low density, high hardness, low thermal expansion coefficient and high elastic modulus [15]. The reaction forms $\mathrm{Mg}_{2} \mathrm{Si}$ :

$$
\mathrm{L} \rightarrow \mathrm{Al}+\mathrm{Si}+\mathrm{Mg} \mathrm{g}_{2} \mathrm{Si}
$$

$\mathrm{Al}_{2} \mathrm{Cu}$ phase is formed during solidification on the composite [13]. The $\mathrm{Al}_{2} \mathrm{Cu}$ phase is an intermetallic phase which has a porous morphology, and the $\mathrm{Al}_{2} \mathrm{Cu}$ phase is an intermetallic phase that affects decreased the mechanical properties of composite materials [16]. The reaction forms $\mathrm{Al}_{2} \mathrm{Cu}$ [13]:

$$
\mathrm{L} \rightarrow \mathrm{Al}+\mathrm{Si}+\mathrm{Al}_{2} \mathrm{Cu}
$$

$\mathrm{XRD}$ also confirmed the existence of $\mathrm{Mg} \mathrm{g}_{2} \mathrm{Si}$ and $\mathrm{Al}_{2} \mathrm{Cu}$ compounds on Figure 4 . The Spinel $\left(\mathrm{M} \mathrm{gAl}_{2} \mathrm{O}_{4}\right)$ and $\mathrm{MgO}$ phases were seen in the XRD test. The presence of the $\mathrm{MgO}$ compound can increase the bond between the matrix with SiC particles, thereby increasing the mechanical properties [17].

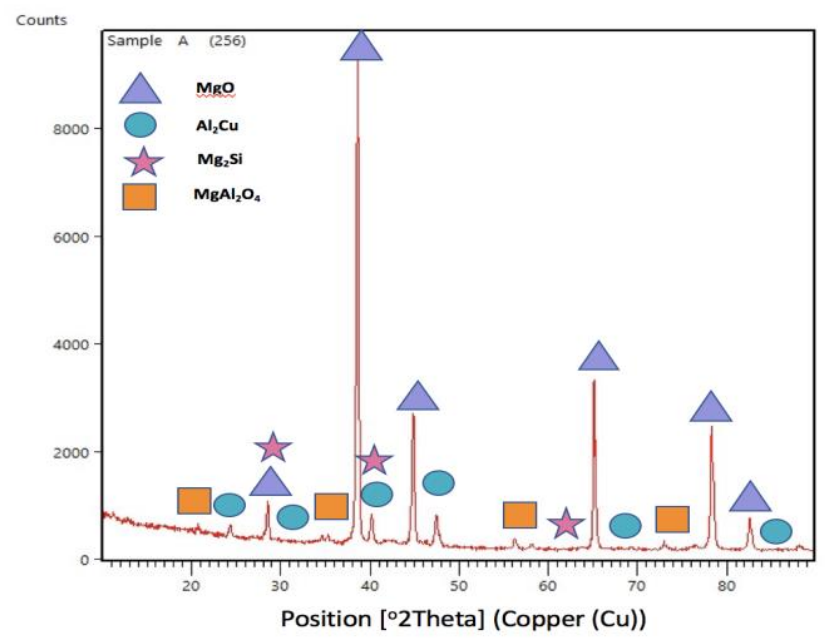

Fig 4. XRD pattern of $A D C 12$ reinforced with $3 \mathrm{vf} \% \mathrm{SiC}$ with addition of $\mathrm{Sr}$ modifier and grain refiner $\mathrm{TiB}$. 


\subsection{Mechanical properties ADC12/ SiC composite}

\subsubsection{Density and porosity}

Based on Figure 5. There is the difference between the theoretical density value and the actual density value of the composite material see in Figure 5, this is due to the formation of porosity due to the presence of $\mathrm{H}_{2}$ gas during the casting process, at a temperature of over $600{ }^{\circ} \mathrm{C}$ will increase the solubility of $\mathrm{H}_{2}$ gas and into the metal, this causes the difference in density value [18].

Figure 5 shows that there is an increase in the porosity value of the composition of the addition of $\mathrm{vf} \% \mathrm{SiC}$ The decrease of the porosity value in the fourth composition is $2.5 \mathrm{vf} \%$ the porosity value is fluctuated due to grain refiner TiB. Grain refiner TiB was effectively nucleating, whereas in the 2 nd composition there may be clustering of $\mathrm{TiB}_{2}$ particles and the gas entrapped in the molten composites so that can affect porosity nucleation [19].
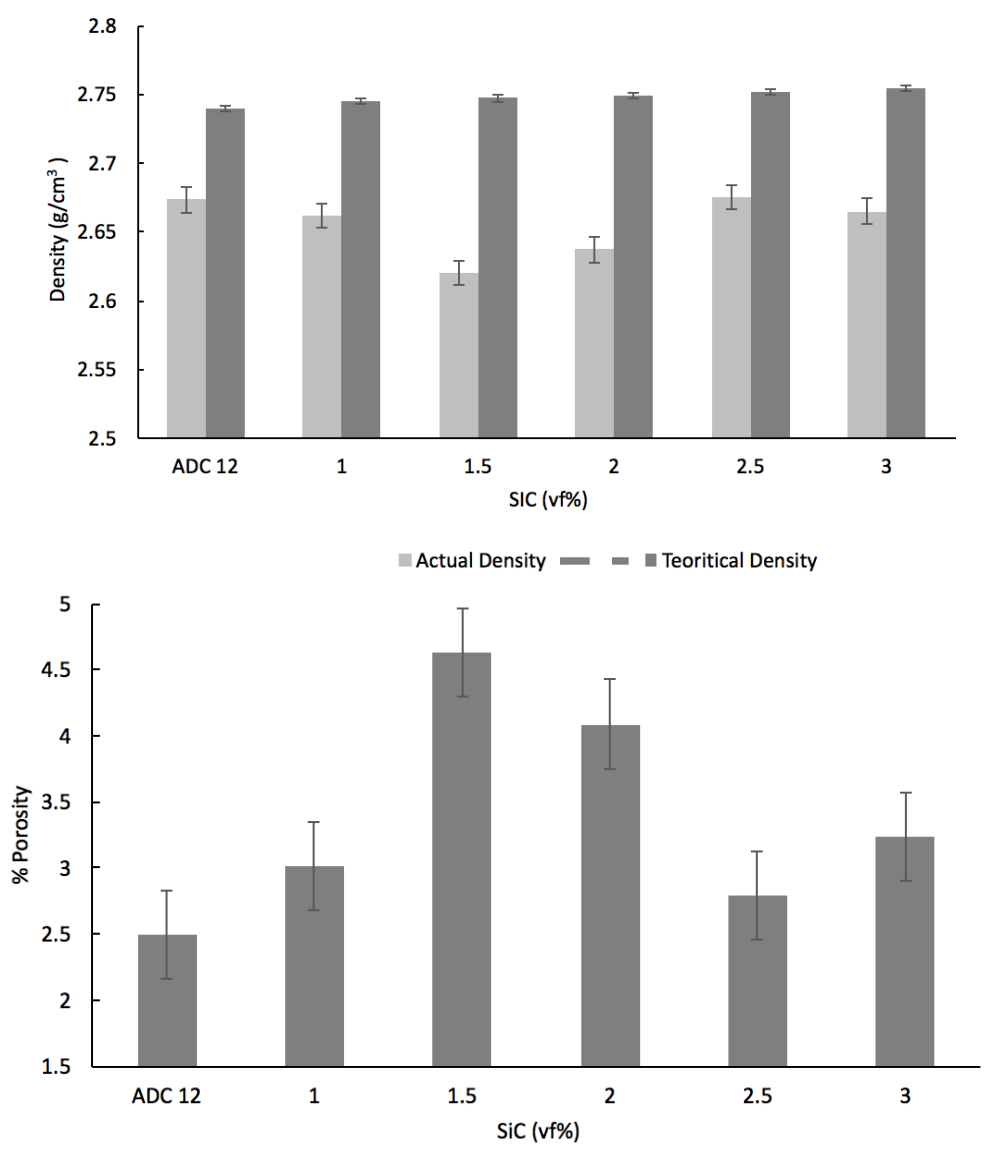

Fig 5. Effect of Adding SiC to Composite Density (left) and Porosity (right) of ADC 12 / SiC with the addition of $\mathrm{Sr}$ modifier and grain refiner TiB.

\subsubsection{Tensile and elongation}

Figure 6 show the elongation values in ADC12 materials of $3 \%$, and ADC 12 composites with $\mathrm{SiC} 1$ variations; $(1.5 ; 2 ; 2.5 ; 3) \%$ vf has the value of elongation was $6.67 \%, 3.02 \%$, 
$2.89 \%, 1.83 \%$, and $3.44 \%$ respectively, from result the tendency of elongation value on composite ADC12 decreased. Based on the literature, in general, the increase of $\mathrm{SiC} \% \mathrm{vf}$ will lead to a significant decrease in elongation [20]. This theory is supported with increased $\mathrm{SiC}$ particles, can increase tensile strength, but decrease the value of plastic deformation, this is due to the decrease of dislocation slip distance with increasing $\mathrm{vf} \% \mathrm{SiC}$ particles and the presence of $\mathrm{SiC}$ can form $\beta$-Al5FeSi phase which can be a crack initiation [21].

Figure 6 shows the tensile strength on composites with $\mathrm{SiC}$ variations of $(1 ; 1.5 ; 2 ; 2.5$; $3) \%$ vf are respectively; $(132,118 ; 133 ; 138 ; 144) \mathrm{MPa}$. The value of composite tensile strength tends to increase, this is proved by the addition of $\mathrm{SiC}$ will increase the tensile strength of a material, this becase of the mechanism of load transfer effect, Hall-Petch Strengthening and Orowan Strengthening [22]. Orowan Strengthening Mechanism, SiC particles will block the movement of dislocations around the particles within the matrix [23].
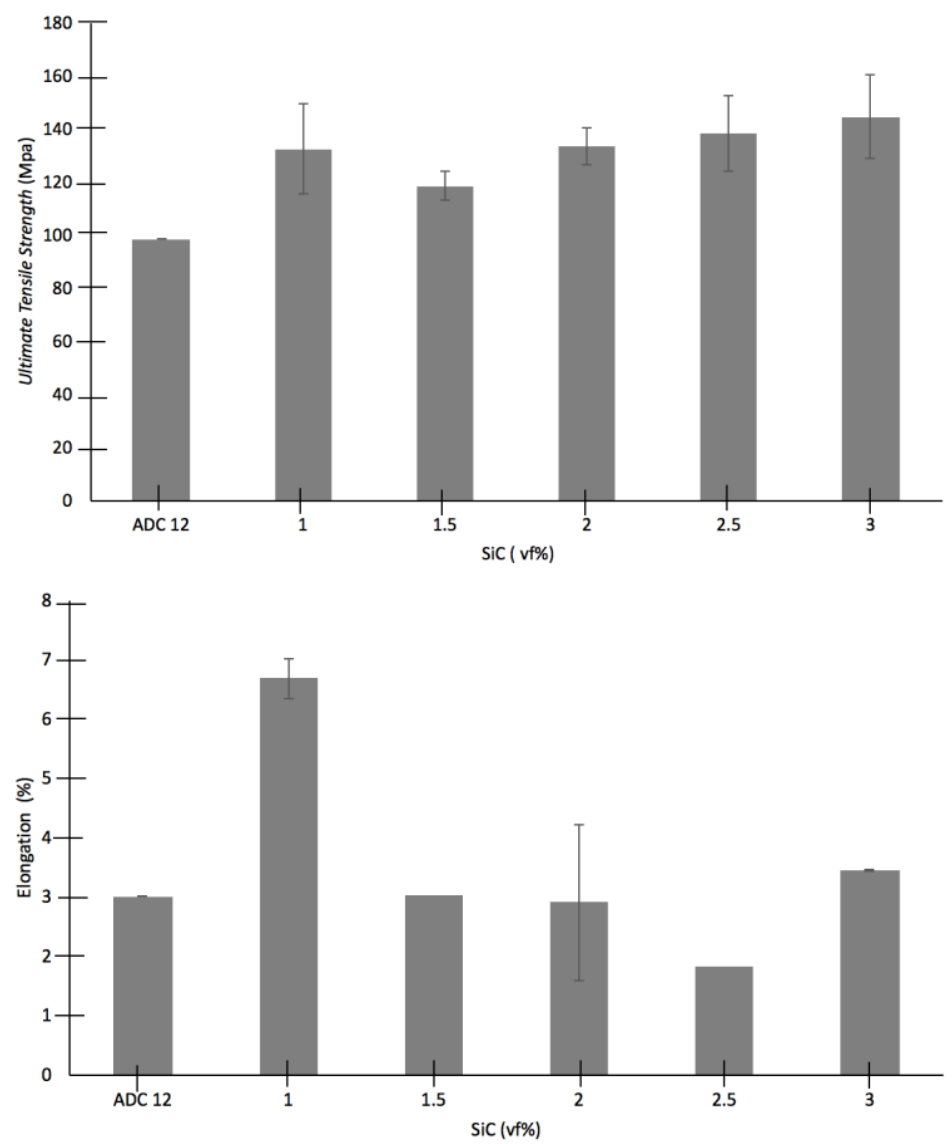

Fig 6. Effect of Adding $\mathrm{SiC}$ to Composite Tensile Strength (left) and Elongation (right) of ADC $12 / \mathrm{SiC}$ with the addition of $\mathrm{Sr}$ modifier and grain refiner $\mathrm{TiB}$.

\subsubsection{Hardness and wear rate}

Figure 7 shows The hardness value of ADC 12 material is $35.03 \mathrm{HRB}$, whereas in $\mathrm{g}$ ADC $12 / \mathrm{SiC}$ composite material with the addition of $\mathrm{Sr}$ and $\mathrm{TiB}$ obtained the optimum hardness at $3 \mathrm{vf} \% \mathrm{SiC}$ composition of $53.4 \mathrm{HRB}$. This is in line with the theory, whereas with 
increasing vf $\% \mathrm{SiC}$ can increase the hardness value because, with the increasing number of reinforcing particles, the possibility of clustering and distribution of particles in heterogeneous matrices can increase the hardness value of the material [3]. In addition to increasing the $\mathrm{SiC} \%$ vf, modifying the aluminium matrix grain size can also increase the hardness of the material, such as by adding the Ti element as a grain refiner and shrinking the grain size, so that grain boundaries are formed increasing and can inhibit dislocation movements [19].
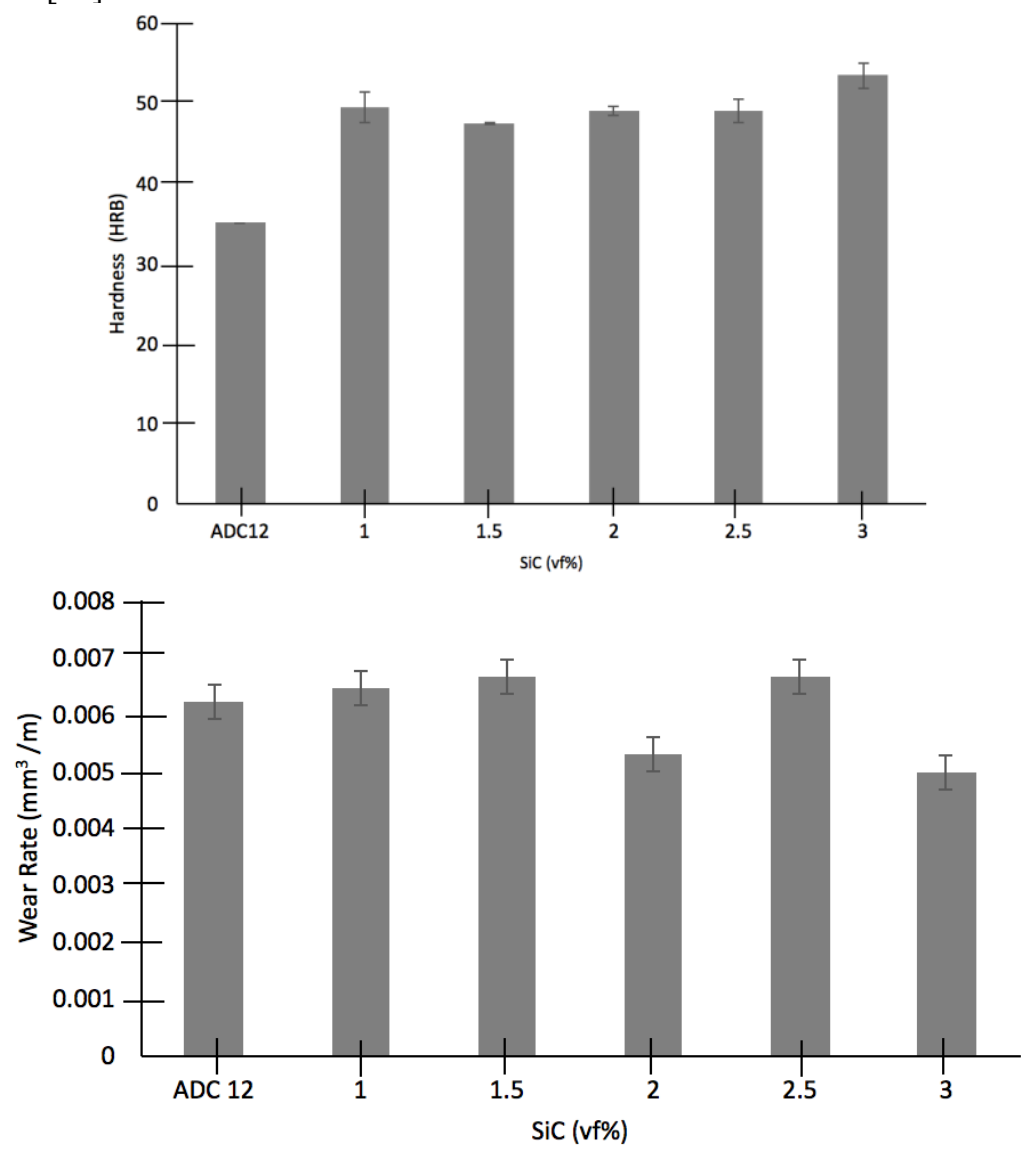

Fig 7. Effect of Adding SiC to Composite Hardness (left) and Wear Rate (right) of ADC 12 / SiC with the addition of $\mathrm{Sr}$ modifier and grain refiner TiB.

Figure 7 can be seen, that the value of the wear rate tends to decrease. The lowest wear rate is on the composite $\mathrm{ADC} 12 / \mathrm{SiC}$ with composition fifth with $\mathrm{SiC} 3 \mathrm{vf} \%$ which is 0.004 $9 \mathrm{~mm}^{3} \mathrm{~m}^{-1}$, which has a lower wear rate than the composite base rate of ADC 12 composite material. This is due to the addition of $\mathrm{SiC}$ increases hardness in composite materials. The graph of wear rate is following the previous author revealed that increasing the hardness value will decrease the wear rate [24].

\section{Conclusion}

The results show that there is an increase in the mechanical properties of aluminium ADC $12 / \mathrm{SiC}$ composite compared to unreinforced with the value of $144 \mathrm{MPa}$ of strength and 53 $\mathrm{HRB}$ of hardness. As a result, the higher addition of the $\mathrm{SiC}$ results in the better mechanical properties for the composite. The addition of $\mathrm{SiC}$ particles can improve the mechanical 
properties of composite materials by the mechanism of load transfer effect, hall-petch strengthening and orowan strenthening. With the addition of $\%, \mathrm{SiC}$ vf $\%$ decreased the SDAS value. The addition of the TiB as grain refiner produces the $\mathrm{Al}_{3} \mathrm{Ti}$ phase which will perform the $\alpha$-Aluminum nucleation of the composite material and leads the uniform distribution of $\mathrm{SiC}$ particles. Phases formed on ADC 12 / SiC composites with the addition of $\mathrm{Sr}$ and Grain Refiner TiB that were $\alpha$-Al, $\mathrm{Mg}_{2} \mathrm{Si}$ primer, $\mathrm{Mg}_{2} \mathrm{Si}$ binary eutectic, $\beta$ $(\mathrm{AlFeSi})$ and $\mathrm{Al}_{2} \mathrm{Cu}$, which are known from the $\mathrm{XRD}$ resluts.

Authors would like to express their gratitude for financial support from the Directorate of Research and Community Services (DRPM), Universitas Indonesia, through International Publications Index for Final Year Students Projects Grant (PITTA) 2018 with contract number: 2378/UN2.R3.1/HKP.05.00/2018.

\section{References}

1. F.C. Campbell, Manufacturing process for advance composite. Oxford: Elsevier Advance Technology (2004). p. 3-37. https://theeye.eu/public/Books/Materials $\% 20$ science $\% 20$ and $\% 20$ engineering/M321\%20Compos ites $\% 20$ manufacturing/Flake $\% 20 \mathrm{C} \% 20$ Campbell $\% 20 \mathrm{Jr} \% 20$ Manufacturing $\% 20$ Proces ses $\% 20$ for $\% 20$ Advanced $\% 20$ Composites.pdf

2. A.P. Bayuseno, N.A. Chamdani. Rotasi 13,1:17-23(2013). https://ejournal.undip.ac.id/index.php/rotasi/article/view/4419

3. G.H. Majzoobi, H. Bakhtiari, A. Atrian, M.K. Pipelzadeh, S.J. Hardy, Proc. IMechE Part L: J. Materials: Design and Applications, 0,0:1-13(2015). https://www.academia.edu/26479215/Warm_dynamic_compaction_of_Al6061_SiC_n anocomposite powders

4. Association Aluminium, Technical committee on product standards technical procedures manual, Arlington: Association Alluminium, Inc (2015). p. 42. https://www.aluminum.org/sites/default/files/TCPS_Technical_Procedure_Manual_Ap ril_2015.pdf

5. Z. Tan, Z. Cheng, G. Fan, G. Ji, J. Zhang, R. Xu, et al., Mater. Des., 90:845851(2016).

https://www.researchgate.net/publication/284103206_Effect of particle_size on the thermal and mechanical_properties_of aluminum_composites_reinforced with_SiC and diamond

6. H.R. Lashgari, A.R. Sufizadeh, M. Emamy, Mater. Des., 31,4:2187-2195(2010). https://www.researchgate.net/publication/248465379_The_effect_of_strontium_on_the microstructure and wear_properties_of_A356-10B_4C_cast_composites

7. S. Farahany, A. Ourdjini, M.H. Idrsi, S.G. Shabestari, Thermochim. Acta, 559:5968(2013).

https://www.researchgate.net/publication/235997987_Evaluation_of the Effect_of_Bi Sb_Sr_and Cooling_Condition on Eutectic Phases in an Al-Si-

$\mathrm{Cu}$ Alloy ADC12 by In-situ Thermal_Analysis

8. M. Emamy, A. Razaghian, H.R. Lashgari, R. Abbasi, Mater. Sci. Eng. A, 485,12:210-217(2008).

https://www.researchgate.net/publication/223271663 The effect_of_Al-5Ti$1 \mathrm{~B}$ on the microstructure hardness and tensile properties of $\mathrm{Al} 2 \mathrm{O} 3$ and SiCcontaining metal-matrix composites

9. H. Liao, Y. Sun, G. Sun, Mater. Sci. Eng. A, 335,1-2:62-66(2002). https://www.researchgate.net/publication/222868130_Correlation between mechanica 1 properties_and amount_of_dendritic_a-Al_phase_in as-cast_near-eutectic_Al- 
116_Si_alloys_modified_with_strontium

10. A. Sangghaleh, M. Halali, Appl. Surf. Sci., 255,19:8202-8206(2009).

https://www.sciencedirect.com/science/article/pii/S0169433209006394

11. Y. Zhao, X. Liu, Y. Yang, T. Bian, China Foundry, 11,2,:91-97(2014). https://www.researchgate.net/publication/248195603_Effect_of magnesium addition on the wetting of alumina by aluminium

12. C. Lee, Mater. Sci. Eng. A, 668:152-159(2016). https://www.sciencedirect.com/science/article/abs/pii/S0921509316305664

13. L.F Mondolfo. Aluminum alloys: Structure and properties. London;Boston Butterworths (1976). p. 973.

https://www.sciencedirect.com/book/9780408709323/aluminum-alloys

14. B. Suárez-Peña, J. Asensio-Lozano, Scripta Materialia, 54,9:1543-1548(2006). https://www.sciencedirect.com/science/article/pii/S1359646206000923

15. Y.X. Gao, J.Z. Yi, P.D. Lee, T.C. Lindley, Acta Mater., 52,19:5435-5449(2004). https://www.sciencedirect.com/science/article/abs/pii/S1359645404004446

16. H. Nagaumi, S. Suzuki, T. Okane, T. Umeda, Mater. Trans., 47,11:2821-2827(2006). https://www.jstage.jst.go.jp/article/matertrans/47/11/47_11_2821/_article

17. F. Delannay, L. Froyen, A. Deruyttere, Journal of Material Science, 22,1:1-16(1987). https://link.springer.com/article/10.1007/BF01160545

18. R.S. Rana, R. Purohit, S. Das, Int. J. Sci. Res. Publ., 2,6:1-7(2012). http://www.ijsrp.org/research_paper_jun2012/ijsrp-June-2012-10.pdf

19. M. Easton, D. StJohn, Metall. Mater. Trans. A, 30,6:1613-1623(1999). https://www.academia.edu/13901359/Grain_refinement_of_aluminum_alloys_Part_I. the nucleant and solute paradigms_a review of the literature

20. A. Mazahery and M. O. Shabani, Powder Technol., 217:558-565(2012). https://www.researchgate.net/publication/256831875 Nano-

sized_silicon_carbide_reinforced_commercial_casting_aluminum_alloy_matrix_Exper imental_and_novel_modeling_evaluation

21. M. SONG, Trans. Nonferrous Met. Soc. China (English Ed.), 19,6:1400-1404(2009). https://www.researchgate.net/publication/240440431_Effects_of_volume_fraction_of SiC_particles_on_mechanical_properties_of_SiCAl_composites

22. R. Casati, M. Vedani, Metals (Basel)., 4,1:65-83(2014). https://www.mdpi.com/2075$\underline{4701 / 4 / 1 / 65 / p d f}$

23. A. Mazahery, M.O. Shabani, Trans. Nonferrous Met. Soc. China (English Ed.), 22,2:275-280(2012).

https://www.researchgate.net/publication/257443682_Characterization_of_cast_A356 alloy reinforced with nano SiC composites

24. P.L. M enezes, S.P. Ingole, M. Nosonovsky, S.V. Kailas, M.R. Lovell, Tribology for Scientists and Engineers. New York: Springer (2013). p. 921. https://www.researchgate.net/publication/280566932_Tribology_for_Scientists_and_E ngineers 